\title{
Primigravida's Readiness in Dealing with Childbirth Considering the Mother's Social Characteristics
}

\author{
Erma Nur Fauziandari* \\ Karya Husada Health Polytechnic Yogyakarta, Indonesia \\ Corresponding author:erma.nf@gmail.com
}

\begin{abstract}
Background: Indonesian Population Demographic Survey (IDHS) in 2017 stated that the Maternal Mortality Rate (MMR) in Indonesia was 309/100,000 live births. According to Ristica (2017) the high maternal mortality rate in Indonesia is caused by the unpreparedness of the mother in facing childbirth. Maternal unpreparedness is usually seen among primigravida who struggle in preparing for childbirth as they have yet experience in delivering. Geniofam in Muthoharoh explained (2018) the factors that influence mother's readiness including knowledge, education, socio-culture and economy.

Purpose: This study aimed to determine the mother social characteristic (age, education, occupation) that affect the readiness of primigravida in facing childbirth.

Methods: This type of research is analytical research with an observational approach. The sample in this study involved 53 primigravida on the third trimester of pregnancy. Data collection was carried out by filling out questionnaires on the readiness of mothers to face childbirth by respondents.

Results: The results of statistical tests showed that age, education, or occupation did not affect mother's readiness in dealing with childbirth with $p$ value $>0.05$.

Conclusion: Mother's social characteristics do not affect the readiness of primigravida in facing childbirth.
\end{abstract}

Keywords: Childbirth, Primigravida Readiness, Mother's Social Characteristics. 


\section{Journal Of Nursing Practice}

http://thejnp.org

ISSN: 2614-3488 (print); 2614-3496 (online)

Vol.5 No.1. October 2021. Page.65-69

\section{BACKGROUND}

Following the results released by the Indonesian Population Demographic Survey (IDHS) in 2017, the Maternal Mortality Rate (MMR) in Indonesia is 309/100,000 live births. Ristica (2017) stated that the high MMR in Indonesia is caused by the unpreparedness of the mother in facing childbirth. Maternal unpreparedness mainly occurs in primigravida who have difficulty in preparing for childbirth due to lack of information and assistance. The unpreparedness of the mother causes delay in the management of obstetric complications and hinders them from not getting appropriate and timely services, resulting in three delays in referrals. The first delay is related to making decisions to referring the patient; second, a delay in reaching health facilities; and the last delay is in obtaining help at health facilities.

Delivery readiness is a way to assess the success of the delivery process. A mother who are not mentally ready in facing childbirth is likely to experience various complications in childbirth. Geniofam in Muthoharoh (2018) asserted that the factors influencing mother's readiness include knowledge, education, socio-culture and economy. The mother's social characteristics that will be tested in this study are education, occupation and age. Qurniasih, (2014) claimed that age affects a person's readiness. Age affects a person's maturity in thinking as it refers to the experience one has. The younger the age, the less prepared a person is in facing childbirth.

In addition to those factors, the role of the midwife is very crucial in providing assistance to pregnant women. Pregnant mother. The role of midwives in ANC examination is quite significant, starting from providing knowledge to pregnant women about preparation for labor and the delivery process. The purpose of this study was to determine the effect of education, occupation and maternal age on the readiness of primigravida in delivery assistance.

\section{OBJECTIVE}

This study aimed to determine the mother social characteristic (age, education, occupation) that affect the readiness of primigravida in facing childbirth

\section{METHODS}

This research is an analytic study with an observational approach. The population in this study was pregnant women in the area of Prambanan Public Health Center Yogyakarta. The samples taken in this study were pregnant women in the third trimester of pregnancy with a sampling technique namely purposive sampling by considering certain criteria. To be eligible for this observation these women must be primigravida with a minimum gestational age of 28 weeks. Sampling was carried out in September to November 2020. Data were collected using a questionnaire with the assistance of the research team. Respondents filled out questionnaires containing data on identity, age, occupation, and education. Then fill out a questionnaire about the mother's readiness in facing childbirth. The obtained data then transferred into the master table and then tabulated the data. Descriptive analysis is displayed in the frequency distribution table to be analyzed with the frequency distribution table and continued with Chi Square statistical analysis. 


\section{Journal Of Nursing Practice}

RESULT

Table 1. Frequency Distribution of Respondents by Age

\begin{tabular}{llcc}
\hline \multicolumn{1}{c}{ No } & \multicolumn{1}{c}{ Age } & N & $\%$ \\
\hline 1 & Healthy Reproduction & 45 & 84.9 \\
2 & Not Healthy & 8 & 15.1 \\
& Reproduction & & \\
\hline
\end{tabular}

Based on table 1 , we can conclude that $84.9 \%$ of respondents are in healthy reproductive age.

Table 2. Frequency distribution of respondents based on education

\begin{tabular}{|c|c|c|c|}
\hline No & Education & $\mathrm{N}$ & $\%$ \\
\hline 1 & High & 13 & 24.5 \\
\hline 2 & Sencondary & 38 & 71.7 \\
\hline 3 & Basic & 2 & 3.8 \\
\hline
\end{tabular}

Table 2 shows that $71.7 \%$ of respondents have a history of secondary education.

Table 3. Frequency distribution of respondents by occupation

\begin{tabular}{|c|c|c|c|}
\hline No & Occupation & $\mathrm{N}$ & $\%$ \\
\hline 1 & Bekerja & 25 & 47.1 \\
\hline 2 & Tidak Bekerja & 28 & 52.8 \\
\hline
\end{tabular}

From table 3 we can say that $47.1 \%$ of respondents are unemployed

Table 4. Frequency distribution of respondents Readiness to face childbirth

\begin{tabular}{llcc}
\hline No & \multicolumn{1}{c}{$\begin{array}{c}\text { Readiness to face } \\
\text { childbirth }\end{array}$} & N & $\%$ \\
\hline 1 & Ready & 44 & 83.01 \\
2 & Not Ready & 9 & 16.99 \\
\hline
\end{tabular}

Table 4 demonstrates that $83.01 \%$ of respondents claim to be ready to face childbirth

Table 5. The results of bivariate analysis of age, education, occupation, on readiness to face childbirth

\begin{tabular}{lrrr}
\hline \multicolumn{1}{c}{ Determinan } & Value & Df & \multicolumn{2}{c}{$\begin{array}{c}\text { Asymptomatic } \\
\text { sig 2-tailed }\end{array}$} \\
\hline Age & .265 & 1 & .607 \\
Occupation & 2.398 & 2 & .301 \\
Education & .833 & 1 & .361
\end{tabular}

Table 5 displays the sig value for age, occupation and education is $>0.05$, the null hypothesis is false. In conclusion, age, occupation and education have no effect on the readiness of primigravida in facing childbirth.

\section{DISCUSSION}

\section{Maternal Age on Childbirth Readiness}

The sig value is found out to be $0.607>0.05$, this means the hypothesis is rejected that there is no influence between age and the readiness of primigravida in facing labor. The result emphasizes that the mothers' age does not affect their readiness in facing childbirth. This result is proven to oppose that of Qurniasih, (2014) which suggested that age affects a person's readiness. Age affects a person's maturity in thinking because it refers to the experience one has. The younger the age, the less prepared a person is in facing childbirth. 


\section{Journal Of Nursing Practice}

http://thejnp.org

ISSN: 2614-3488 (print); 2614-3496 (online)

Vol.5 No.1. October 2021. Page.65-69

In this study there was no influence between age and readiness caused by several other factors. The family support also influences the readiness of primigravida pregnant women in facing childbirth. This is in line with Sepa, Ernawati, and Marlinah (2018) who stated that family support is one of the factors that affect childbirth readiness.

\section{Mother's Occupation on Childbirth Readiness}

The value of sig $0.301>0.05$ therefore the hypothesis is rejected; there is no influence between occupation on the readiness of primigravida in facing childbirth. This result demonstrates that both working and non-working mothers are all ready to face childbirth. The result of this study agrees with the result of a research from Agustina and Utami (2017) that the mother's occupation does not affect readiness in facing childbirth. Out of 53 respondents there were 10 respondents who were not ready to face childbirth, 7 of which are unemployed mothers. The unpreparedness of the respondents was mainly on the terms of physical and cultural readiness. Physical readiness involves physical changes experienced by the mother and the equipment that must be prepared by the mother in facing childbirth, while for cultural preparation refers to the family's assumption that childbirth is a terrifying matter.

\section{Mother's Education on Childbirth Readiness}

The value of sig $0.361>0.05$ means that this hypothesis is also rejected; there is no influence between mother's education and readiness for childbirth. To emphasize, the level of mother's education does not affect the mother's readiness to face labour. This finding is in line with the research of Agustina and Utami (2017) which stated that maternal education does not affect readiness in facing childbirth. The result of this study also supports the results of Oktalia (2016) which mentioned that there is no relationship between maternal education and readiness in facing childbirth. The result of statistical tests on husband's education shows that the higher the husband's education, the greater the mother's readiness to face childbirth. The difference in statistical test results between the education of mothers and husbands may be related to the cultural habits in Indonesia. In Indonesian culture, decisions made in the family is dominant on husbands. This is because the pattern of life in the household in Indonesia is inseparable from environmental factors, customs, social culture and gender.

\section{CONCLUSION}

Based on these statistical tests, it can be concluded that:

Primigravida's age has no effect on readiness for childbirth, Primigravida's occupation has no effect on readiness for childbirth, Primigravida's education has no effect on readiness for childbirth

\section{REFERENCES}

Agustina, Rika and Fitri Siswi Utami. 2017. "Faktor-Faktor Yang Berhubungan Dengan Kesiapan Persalinan Pada Ibu Hamil Di Puskesmas Kasihan 1 Kabupaten Bantul Yogyakarta." Universitas 'Aisyiyah Yogyakarta.

Nurani, 2017 "FAKTOR-FAKTOR YANG BERHUBUNGAN DENGAN KESIAPAN PERSALINAN DI PUSKESMAS JETIS I BANTUL YOGYAKARTA - DIGILIB UNISAYOGYA."

Oktalia, 2016. "View of KESIAPAN IBU MENGHADAPI KEHAMILAN DAN FAKTORFAKTOR YANG MEMPENGARUHINYA."

Ristica, Hubungan Pengetahuan Sikap dan Dukungan Keluarga Ibu Primigravida, dengan

Persiapan Persalinan Normal DiBPM Khairani Shinta 2017. "MENARA Ilmu Vol. XI 


\section{Journal Of Nursing Practice}

http://thejnp.org

ISSN: 2614-3488 (print); 2614-3496 (online)

Vol.5 No.1. October 2021. Page.65-69

Jilid 1 No.78 November 2017.” XI(78):79-86.

Muthoharoh, Husnul. 2018. "Hubungan Pengetahuan Ibu Primigravida Dengan Kesiapan Ibu Dalam Menghadapi Persalinan Di Wilayah Kerja Puskesmas Deket Kabupaten Lamongan." Strada Jurnal Ilmiah Kesehatan 7(1):40-46.

Sepa, I., Ernawati, and Marlinah. 2018. "Faktor Yang Mempengaruhi Kesiapan Ibu Dengan Pre-Eklamsia Dalam Menghadapi Persalinan Di Poli KIA Puskesmas Sudiang." 12:16.

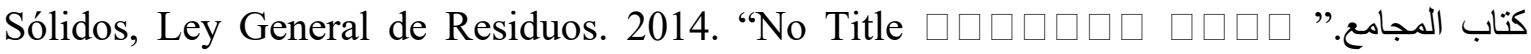
2(5):255. 